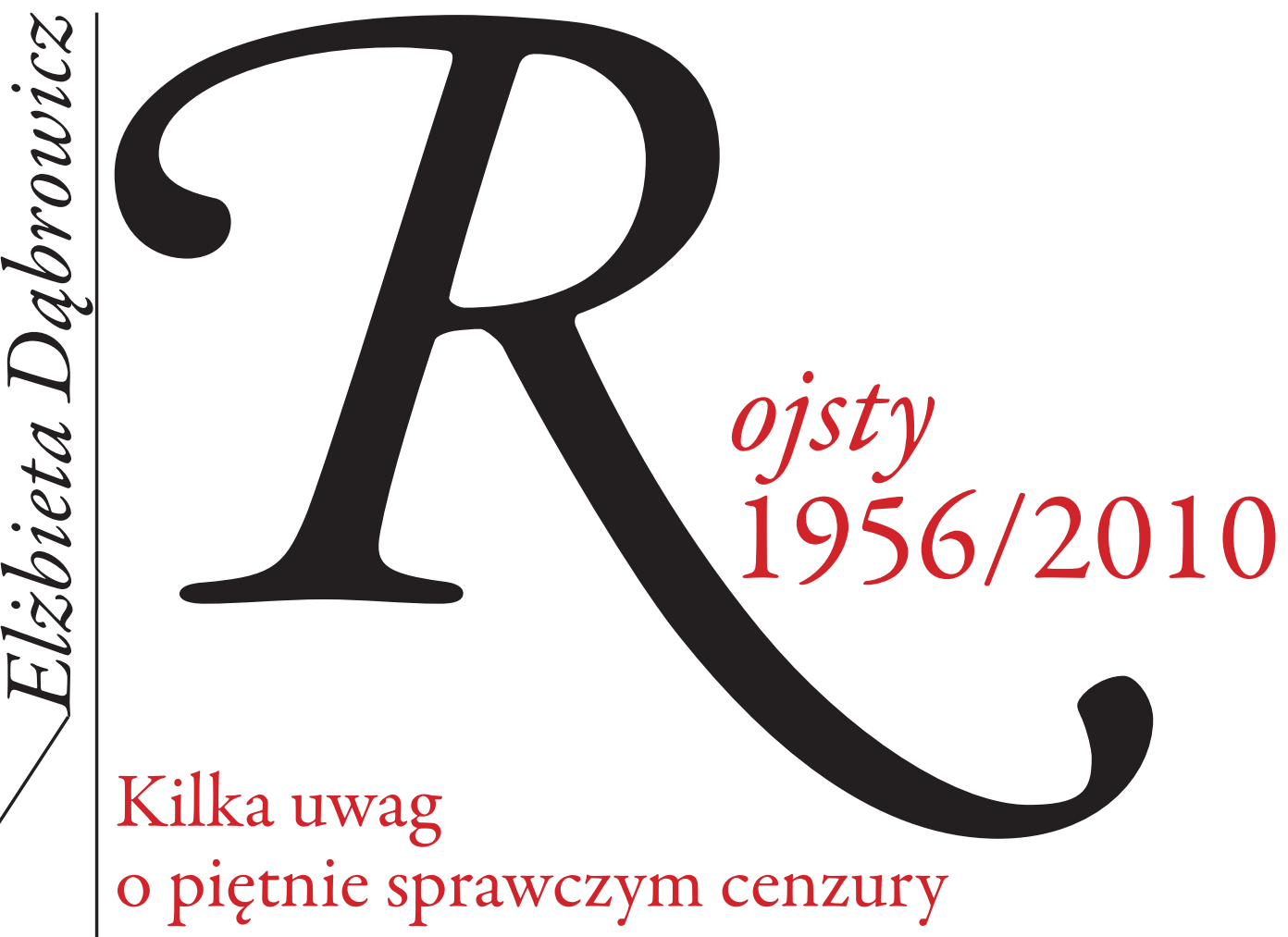

\title{
Edycja historyczno-krytyczna
}

W numerze „Przeglądu Politycznego” poświęconym setnej rocznicy wybuchu pierwszej wojny światowej Łukasz Musiał komentuje z atencją krytyczne wydanie ${ }^{1}$ In Stablgewittern Ernsta Jüngera, „Homera europejskiego wieku żelaza”. Rzecz istotnie godna odnotowania, bo dzieło to - kluczowa pozycja wojennego kanonu europejskiego - stanowiła dla edytorów wyzwanie karkołomne. Jünger wielokrotnie tekst przekształcał. Przeformułowania schodziły zaś tak głęboko, że siedem kolejnych wersji utworu (Musiał pisze o sześciu wersjach), sporządzonych między 1920 a 1978 rokiem, należy traktować jako samodzielne dokonania ideowo-artystyczne. Wydanie z 2013 roku skrupulatnie dokumentuje ową metamorficzność dzieła ${ }^{3}$. W omówieniu Musiała pada pytanie nurtujące wszystkich komentatorów eposu $W$ stalowych burzach: jak wyjaśnić autorską uporczywość w nawracaniu do tekstu? Przejaw to koniunkturalizmu pisarza czy też raczej, łagodniej rzecz ujmując, niestałości jego poglądów ? Autor artykułu proponuje wykładnię jeszcze inną: „[...] można to nazwać [...] obsesją nadawania formy temu, co zawsze wymyka się formie: niszczącemu doświadczeniu śmierci, z którą tylekroć Jünger stawał oko w oko. I doświadczeniu żałoby” ${ }^{4}$. Ponawiany wciąż akt twórczy zostaje więc utożsamiony z przepracowywaniem traumy wojennej. Jest to niewątpliwie rozwiązanie poręczne; umożliwia Musiałowi pozostawienie nieco z boku lektury kontekstowej, w tym przypadku niesłychanie pracochłonnej i trudnej do przeprowadzenia w ciasnych ramach artykułu prasowego. Takie ujęcie ma jednak zasadniczy mankament. Nazbyt marginalizuje to, co w związku z wydaniem In Stablgewittern wydaje się najistotniej- 
sze i ważne również w odniesieniu do literatury polskiej. Jego wielokształtność sprzyja bowiem postawieniu kwestii z pozoru banalnej, lecz w praktyce często lekceważonej: związku interpretacji z konkretną edycyjną postacią utworu. Musiał zdaje sobie z tego sprawę, nie na tyle jednak, by ze wskazaną zależnością konsekwentnie się liczyć we własnych poczynaniach analitycznych ${ }^{5}$. Z jednej strony chwali wzorową niemiecką edycję z 2013 roku, z drugiej zaciera kontury poszczególnych wersji, starając się znaleźć klucz uniwersalny, w jakimś stopniu pasujący do każdej z nich. Niekonsekwencji tej na dobrą sprawę nie mógł uniknąć choćby z tego względu, że pisząc o dziele traktującym wprawdzie o wojnie światowej, doświadczeniu zdecydowanie ponadlokalnym i ponadnarodowym, lecz o dziele pochodzącym z niemieckiego kręgu językowego, zwracał się do czytelnika polskiego, który nawet jeśli sięgnie po oryginał, będzie skazany na lekturę w mniejszym lub większym stopniu powierzchowną. Cóż bowiem z tego, że obcokrajowiec przyswoi sobie wiedzę na temat źródła tytułu In Stahlgewittern. Jünger, używając sformułowania z Eddy, nie domagał się od swego czytelnika wiedzy encyklopedycznej, lecz uruchamiał - nieraz milczące czy nieoczywiste złoża tradycji wspólnej piszącemu i publiczności ${ }^{6}$. Kulturowa bariera nie stanowi jednak przeszkody, by o wydaniu, które przed polskim czytelnikiem (i każdym obcym) stawia zbyt wysokie wymagania, pisać z poczuciem głębokiego sensu. Wystarczy edycję taką potraktować jako przedsięwzięcie modelowe. Wartość bowiem największa owego wydania historyczno-krytycznego polega na tym, że pozwala na śledzenie twórczego przedsięwzięcia od wersji pierwszej do ostatniej oraz na metodyczną analizę różnic między wersjami kolejnymi. Dzięki obserwacji zmian jaśniej widać nie tyle autorską obsesję, ile intencję, za każdym razem uobecnianą inaczej w literackiej materii, inaczej wikłaną w konteksty bieżące i historyczne. Edycja tego rodzaju jest zaś owszem - dziełem pomnikowym, co autor artykułu podkreśla, lecz może być także silnym impulsem recepcyjnym, skłaniającym do przemyślenia na nowo większych fragmentów bądź warstw zbiorowego dziedzictwa.

Wychodząc od artykułu o proteuszowym dziele, które udostępniono w optymalnej formie wydawniczej, chcę rozważyć zagadnienie podobne, choć związane z całkiem inną inicjatywą edytorską. W 2010 roku pod szyldem Biblioteki „Gazety Wyborczej” ukazało się pierwsze zbiorowe (lecz jeszcze niekompletne) wydanie dzieł Tadeusza Konwickiego. Książki wybrane otworzyła powieść Dziura w niebie. W drugim tomie opublikowano Sennik wspótczesny, dalej Wniebowstąpienie i Zwierzocztekoupiora. W tomie piątym znalazły się: Nic albo nic i Kronika wypadków mitosnych. W szóstym: Kalendarz i klepsydra oraz Kompleks polski. W siódmym: Mata apoka- lipsa. W ósmym: Wschody i zachody księżyca. W dziewiątym: Rzeka podziemna, podziemne ptaki tudzież Nowy Świat i okolice. W kolejnym: Bobiń. W jedenastym: Zorze wieczorne i Czytadto. W tomie finalnym, dwunastym, Pamflet na siebie, ostatni utwór pisarza, połączono z Rojstami - jego niedoszłym debiutem książkowym.

Edycja Agory zasługuje na uwagę nie tylko dlatego, że jest pierwszą próbą tego rodzaju w odniesieniu do twórczości Konwickiego. Jej walor podstawowy polega na tym, że edytor sięgnął do autografów, poprawił błędy i omyłki, a co najistotniejsze, przywrócił partie tekstów niedopuszczone do druku w edycjach PRL-owskich ${ }^{7}$. Czytelnik ma zatem wreszcie możliwość poznać teksty głośnych swego czasu utworów w innych wersjach niż te, które wcześniej weszły do publicznego obiegu. Jest to niewątpliwie praktyka wydawnicza, którą należałoby objąć wszystkich ważniejszych twórców PRL-owskich (nie rezygnując dla wątpliwych oszczędności z komentarza krytycznego!), co od chwili zniesienia cenzury wielokrotnie postulowano, lecz bez spektakularnych efektów. Konkretne propozycje z tego zakresu zgłosiła ostatnio Kamila Budrowska, optując za „edycjami przywróconymi”, w których znalazłyby się na powrót fragmenty wykreślone czy zmienione przez cenzurę, odpowiednio zaznaczone i skomentowane ${ }^{8}$. Celem editio restituta - jak badaczka nazywa proponowany typ wydania - byłaby próba „odtworzenia autorskiego zamysłu”, zatem postaci tekstu sprzed „jakichkolwiek udokumentowanych nacisków" więc o to, by - na ile to możliwe - przywrócić autorowi stan względnej swobody twórczej. Ale nie tylko o to, bo przecież oznaczając miejsca dotknięte interwencją cenzorską, odsłoniłoby się zarazem przed czytelnikiem - co wydaje mi się szczególnie poznawczo cenne - pole negocjacji między pisarzem a wydawnictwem i urzędem cenzorskim. Dzieło opublikowane pod cenzurą okazywałoby się efektem czy też skutkiem uzgodnień między pisarzem a instytucjami, od których był zależny. Broniłabym tezy, że na piśmiennicze dziedzictwo po PRL-u, jakkolwiek by je oceniać, składa się zarówno to, co zostało wówczas opublikowane, jak i to, co wykreślono, przeformułowano, zastąpiono czymś innym. Nowe edycje, te „przywrócone”, w odróżnieniu od publikacji PRL-owskich, powinny udostępniać zarówno dzieło wynegocjowane, jak i to, które doznało zmian prostujących intencje autorskie.

Edycję dorobku Tadeusza Konwickiego w postaci Książek zebranych z pewnością trzeba zaliczyć do kategorii editio restituta $\mathrm{z}$ tym zastrzeżeniem jednak, że rozwiązanie, które przyjęto, jest nader dyskusyjne. Jest to wprawdzie wydanie popularne, nie krytyczne, ale okoliczność ta bynajmniej nie działa na korzyść wydawcy. Całą pracę edytorską pozostawiono bo- 
wiem bez komentarza, wskutek czego, nie znając poprzednich wersji utworów, czytelnik (zwłaszcza młodszy, nie pamiętający PRL-u) nie zorientuje się w skali i znaczeniu różnic między wersją przywróconą a ocenzurowaną. Edycja tak pomyślana pokazuje wprawdzie, że cenzura przekłamała intencje autora, ale ogranicza szanse rozpoznania w lekturze charakteru i zasięgu kontrowersji dzielących elitę władzy oraz opinię publiczną w czasach publikacji PRL-owskiej.

Zważywszy na istotną rolę cenzury jako czynnika współtworzącego ówczesną kulturę polską, również wydania popularne literatury tamtych czasów powinny zawierać informację o dokonanych ingerencjach. PRL nie skończył się przecież z dnia na dzień. Odwleczone skutki ówczesnej polityki kulturalnej trapią nas do dzisiaj. Rozwiązaniem ze wszech miar pożądanym byłaby więc krytyczna - historyczno-krytyczna - edycja łącząca dwie wersje tekstu: dopuszczoną do obiegu w PRL-u i nieocenzurowaną. Minimalnym wymogiem w tym względzie powinno stać się oznaczanie owych zmian w tekście udostępnianym czytelnikowi; w tekście głównym, a przy rozleglejszych skreśleniach w przypisach. Jak wiadomo, cenzura dokonywała nieraz zmian bardzo głębokich, a ich wiarygodne oszacowanie wymagałoby analizy porównawczej dwóch (jeśli nie więcej) wersji utworu, traktowanych jako osobne w gruncie rzeczy teksty. Nie ma sensu postulowanie takiego trybu edytorskiego w stosunku do wszystkich wznawianych utworów, które wskutek cenzury ucierpiały. Z góry wiadomo, że projektu tak szeroko zakrojonego nie dałoby się zrealizować nie tylko ze względu na ograniczenia finansowe, ale też z powodu niekompletności dokumentacji. Byłaby natomiast do pomyślenia seria wydawnicza złożona z dziesięciu - powiedzmy - starannie wybranych utworów, należących do kanonu literatury PRL-owskiej, wydanych pod jedną okładką w dwóch wersjach, co pozwoliłoby każdą z nich przeczytać jako integralny tekst od początku do końca, z solidnym komentarzem oraz przedrukiem recenzji cenzorskich tudzież oficjalnych, pisanych często również na odgórne zlecenie.

Pośród kandydatur nie do pominięcia w postulowanej tu serii widziałabym Rojsty Tadeusza Konwickiego. Z kilku powodów. Najpierw dlatego, że powieść niedopuszczoną do druku w 1948 roku wydano w 1956 roku z licznymi zmianami w stosunku do wersji pierwotnej. Dlatego również, że dotyczyła niewygodnego w PRL-u tematu partyzantki antybolszewickiej, który trwale naznaczył całą twórczość autora Rojstów, a po 1989 roku odżył jako pamięć o „żołnierzach wyklętych”, budząc zresztą niemałe kontrowersje. Dlatego też, że jest to powieść o ciekawej recepcji literaturoznawczej, by wspomnieć wypowiedzi Kazimierza Wyki, Marii Janion, Hanny Gosk czy Dariusza Skórczewskiego. Dlatego wreszcie, że niedawno ponownie we- szła do obiegu, lecz w wersji autorskiej, odmiennej od wydania z 1956 roku i bez objaśnienia tych różnic.

Rojstom w Ksiażkach wybranych wyznaczono ważną pozycję - umieszczono je na końcu wydania, przez co jako utwór chronologicznie pierwszy stały się swego rodzaju klamrą dla całej twórczości pisarza. Ten zabieg kompozycyjny podkreśla znaczenie powieści, ale też maskuje do pewnego stopnia pominięcie wczesnych utworów pisarza, najbardziej skażonych ideologicznie, co zresztą uważam za decyzję karygodną, bo fałszującą cały dorobek Konwickiego. Za Rojstami, chociaż powstały w późnych latach czterdziestych, przemówiła pewnie ich ówczesna niecenzuralność tudzież odwilżowa aura towarzysząca pierwszemu wydaniu, przede wszystkim zaś „,wileńskość, która przenika nieomal cale pisarstwo autora Sennika wspótczesnego. Nieobojętne były też z pewnością referencje udzielone tej powieści przez Marię Janion ${ }^{10}$. Biorąc jednak pod uwagę świadectwa recepcyjne, niecenzuralności Rojstów nie traktowano jako specjalnego tytułu do chwały autorskiej. W recenzjach z 1956 roku wskazywano na problematyczność decyzji zamykającej Rojstom drogę do publikacji w $1948 \mathrm{roku}^{11}$. W najnowszej interpretacji powieści, skoncentrowanej na analizie wizerunku relacji między Polakami a Rosjanami, Skórczewski dowiódł zaś, jak dalece utwór ten (analizował tekst wydany w 1956 roku) potwierdzał i utrwalał hegemonię sowiecką na „Kresach Wschodnich”' ${ }^{2}$.

Postulując namysł nad dwoma wersjami powieści: dopuszczoną do druku w 1956 roku oraz nieocenzurowaną, nie szukam argumentów ani za Rojstami, ani przeciw nim. Chciałabym jedynie wykazać, jak dalece ingerencja cenzury Rojsty zmieniła. Analiza porównawcza dwóch wersji utworu przemówi - jak się spodziewam - na rzecz jego edycji w podwojonej postaci, z wyraźnym oznaczeniem miejsc zmienionych w wydaniu odwilżowym.

\section{Rojsty i Rojsty}

Rojsty, które odtworzył z autografu Przemysław Kaniecki, różnią się w wielu miejscach od tekstu edycji odwilżowej, ale tylko jeden raz odstępstwo zostaje czytelnikowi zasygnalizowane, mianowicie rozdział osiemnasty - nieistniejący we wcześniejszych wydaniach - został opatrzony informacją o jego rekonstrukcji na podstawie rękopisu. Moje dalsze rozważania będą odnosiły się do zamieszczonego niżej zestawienia fragmentów różniących dwie wersje utworu z konsekwencjami dla jego architektury, stylu, konstrukcji postaci, konsekwencjami idącymi więc bardzo daleko, co sprawia, że Rojsty zrekonstruowane są w gruncie rzeczy powieścią inną aniżeli te z 1956 roku. 


\begin{tabular}{|c|c|c|}
\hline & Rojsty 1956 & Rojsty 2010 \\
\hline 1. & $\begin{array}{l}\text { Ja byłem tylko miesiąc w oddziale. Przyłączyłem się do } \\
\text { piętnastej brygady. }(18)^{13}\end{array}$ & $\begin{array}{l}\text { Ja tylko w akcji na Wilno brałem udział. Przyłączyłem się wtedy do piętna- } \\
\text { stej brygady. (153) }\end{array}$ \\
\hline 2. & $\begin{array}{l}\text { Myślałem, że się rozchoruję, kiedy przyszła wieść, że } \\
\text { Ruscy weszli na Pragę. (19) }\end{array}$ & Myślałem, że się rozchoruję, gdy przyszła wieść o kapitulacji. (153) \\
\hline 3. & $\begin{array}{l}\text { - Białorusini pójdą z nami - zgasił mnie brunet. - } \\
\text { Myśmy te ziemie kolonizowali od kilkuset lat. Niech Pan } \\
\text { się przejdzie po Wilnie. (19) }\end{array}$ & $\begin{array}{l}\text { - Białorusini pójdą za nami - zgasił mnie brunet. - Kultura nasza wywarła } \\
\text { tu swój wpływ. Myśmy te ziemie kolonizowali od kilkuset lat. Niech się Pan } \\
\text { przejdzie po Wilnie. (153) }\end{array}$ \\
\hline 4. & Polak od Polaka żył o dziesiątki kilometrów. (19) & Polak od Polaka był o dziesięć kilometrów. (154) \\
\hline 5. & $\begin{array}{l}\text { Pamiętam - skapitulowałem. } \\
\text { Teraz młodzieńcy w długich butach zaczęli wspominać } \\
\text { ostatnie swoje przewagi, wcześniejsze też czasy, czasy } \\
\text { rozkwitu partyzantki. (20) }\end{array}$ & $\begin{array}{l}\text { Pamiętam - skapitulowałem. } \\
\text { Wiesz, Edek - Ewa odłożyła książkę - tu w naszej dzielnicy był jeden taki } \\
\text { młodzian, który siedział w piwnicy podczas akcji na Wilno, bo mu mama } \\
\text { nie pozwoliła. } \\
\text { Zaśmieliśmy się. } \\
\text { - To my, starzy - przerwał pan Skrzyniewicz - ganiliśmy wtedy pod kulami, } \\
\text { kobiety oddawały chłopcom ostatnie buty, a taki wszarz siedział w piwnicy. } \\
\text { Młodzieńcy w długich butach zaczęli wspominać akcję na Wilno, wcześniej- } \\
\text { sze też czasy, czasy rozkwitu partyzantki. (154) }\end{array}$ \\
\hline 6. & $\begin{array}{l}\text { Podobno dowództwo AK odbyło jakąś konferencję koło } \\
\text { Ruskiej Puszczy. (20) }\end{array}$ & Podobno dowództwo odbyło jakąś konferencję koło Ruskiej Puszczy. (154) \\
\hline 7. & $\begin{array}{l}\text { Znacznie bardziej niż piłsudczyków nienawidził Piwoń } \\
\text { komunistów. (22) }\end{array}$ & $\begin{array}{l}\text { Czasem zdarzało mi się zastanawiać, kogo Piwoń bardziej nienawidził: } \\
\text { piłsudczyków czy komunistów. (156) }\end{array}$ \\
\hline 8. & $\begin{array}{l}\text { Na pogrzebie nie było księdza, paru oficerów-berlin- } \\
\text { gowców odprowadzało go na cmentarz, aby pochować } \\
\text { w nieświęconej ziemi. (22) }\end{array}$ & $\begin{array}{l}\text { Na pogrzebie nie było księdza, paru oficerów (tzw. berlingowców) odprowa- } \\
\text { dzało go na cmentarz, aby pochować w nieświęconej ziemi. (157) }\end{array}$ \\
\hline 9. & $\begin{array}{l}{[\ldots] \text { a inni chronili się przed poborem do wojska fał- }} \\
\text { szywymi „personalausweissami”. Bolszewicy nie zdążyli } \\
\text { jeszcze wydać swoich dokumentów, a wszystkie niemiec- } \\
\text { kie pieczątki i formularze wpadły w ręce AK. (23) }\end{array}$ & $\begin{array}{l}\text { [...] a tysiące chroniły się przed poborem do wojska fałszywymi personalau- } \\
\text { sweissami, gdyż bolszewicy nie zdążyli jeszcze wydać swoich dokumentów, } \\
\text { a wszystkie niemieckie pieczątki i formularze wpadły w ręce AK. (157) }\end{array}$ \\
\hline 10. & $\begin{array}{l}\text { [...] fala zdeterminowania zalała ponownie mój } \\
\text { rozsądek. }(24)\end{array}$ & $\begin{array}{l}\text { [...] fala zdeterminowania zalała ponownie mój rozsądek, iż byłem gotowy } \\
\text { do jak najbardziej szaleńczego szturmu na nieprzyjacielskie pozycje. (158) }\end{array}$ \\
\hline 11. & $\begin{array}{l}\text { Strzelało się białoruskich chłopów, posądzonych o sympa- } \\
\text { tie lub wprost o współpracę z bolszewikami. (29) }\end{array}$ & $\begin{array}{l}\text { Strzelało się, prócz żołnierzy, z którymi sprawa była niełatwa, białoruskich } \\
\text { chłopów posądzanych o sympatie lub wprost współpracę z bolszewikami. } \\
(162)\end{array}$ \\
\hline 12. & $\begin{array}{l}\text { [...] Aktor wyciął w pień posterunek milicji i spalił grana- } \\
\text { tem chałupę. }(33)\end{array}$ & $\begin{array}{l}\text { [...] Aktor wyciął w pień posterunek milicji białoruskiej i spalił granatem } \\
\text { ich chałupę. (165) }\end{array}$ \\
\hline 13. & $\begin{array}{l}\text { Przy rozpętanym żarliwym patriotyzmie łamałem się } \\
\text { dodatkowo ze swoim wrażliwym i czułym } \\
\text { usposobieniem. (35) }\end{array}$ & $\begin{array}{l}\text { Przy rozpętanym żarliwym patriotyzmie, kipiącym w naszych kresowych } \\
\text { sercach, łamałem się dodatkowo ze swoim wrażliwym i czułym usposobie- } \\
\text { niem. (168) }\end{array}$ \\
\hline 14. & Rąbnę mu w łeb - zaszeptał zawzięcie. (37) & Pierdolnę mu w łeb - zaszeptał zawzięcie. (169) \\
\hline 15. & $\begin{array}{l}\text { [...] a za niemieckich czasów był nawet wyrzucony z od- } \\
\text { działu Korbuta. (37-38) }\end{array}$ & $\begin{array}{l}\text { [...] a za czasów niemieckich był nawet wyrzucony z oddziału Narbuta. } \\
(170)\end{array}$ \\
\hline 16. & $\begin{array}{l}\text { Nominację na plutonowego otrzymałem po akcji na } \\
\text { Ławaryszki. (39) }\end{array}$ & Nominację na plutonowego otrzymałem po akcji na Wilno. (171) \\
\hline 17. & Od czerwca ich nie widziałam. (44) & Od samej akcji na Wilno nie widziałam ich. (176) \\
\hline 18. & No, a jeśli zrobią tu plebiscyt? (45) & No a jeśli będzie tu plebiscyt? (177) \\
\hline 19. & $\begin{array}{l}\text { Nie znosiłem tego cynika. } \\
\text { Panna Celinka podniosła fiołkowe oczy [...]. (45) }\end{array}$ & $\begin{array}{l}\text { Nie znosiłem tego cynika. Przypuszczałem, iż był w kontakcie z NKWD, } \\
\text { mówiłem nawet o tym z Kwiatkiem. Panna Celinka podniosła fiołkowe oczy } \\
\text { [...]. (177) }\end{array}$ \\
\hline
\end{tabular}




\begin{tabular}{|c|c|c|}
\hline & Rojsty 1956 & Rojsty 2010 \\
\hline 20. & $\begin{array}{l}\text { Boją się. Powiadają, że w czterdziestym roku dali im } \\
\text { bolszewicy, ale zaraz przyszli Niemcy [...]. (47) }\end{array}$ & $\begin{array}{l}\text { Nie chcą brać. Powiadają, że w czterdziestym roku dali im bolszewicy, ale } \\
\text { zaraz przyszli Niemcy [...]. (178) }\end{array}$ \\
\hline 21. & Wszystkich się bali. (48) & Wszystkich jednakowo nienawidzili. (179) \\
\hline 22. & $\begin{array}{l}\text { A taki Łupaszko to nawet poszedł z Niemcami za } \\
\text { Niemen. (50) }\end{array}$ & $\begin{array}{l}\text { A taki Kuraszko to nawet na akcję wileńską się nie zgodził. Poszedł } \\
\text { z Niemcami za Niemen. (181) }\end{array}$ \\
\hline 23. & Nie stchórzymy. (51) & Nie stchórzymy, do ostatka. (181) \\
\hline 24. & $\begin{array}{l}\text { Część z nich ukrywała się przed poborem do wojska, } \\
\text { resztę zagarnięto na patrolach. }(55)\end{array}$ & $\begin{array}{l}\text { Ukrywali się przed poborem do wojska i w ten sposób chcieli przetrwać do } \\
\text { wiosny. (185) }\end{array}$ \\
\hline 25. & $\begin{array}{l}\text { Po akcji na Ławaryszki przypięto mu czerwono-białą } \\
\text { rozetkę Krzyża Walecznych. (57) }\end{array}$ & $\begin{array}{l}\text { Po akcji na Wilno przypięto mu czerwono-białą rozetkę Krzyża Walecznych. } \\
\text { (186) }\end{array}$ \\
\hline 26. & $\begin{array}{l}{[\ldots] \text { i od razu, nadużywając gramatyki rosyjskiej, wygłosił }} \\
\text { przemowę do drużyny. } \\
\text { Poszedłem na koniec wsi }[\ldots] .(58)\end{array}$ & $\begin{array}{l}{[\ldots] \text { i od razu, nadużywając gramatyki rosyjskiej, wygłosił przemowę do }} \\
\text { drużyny. } \\
\text { - A jebi waszu mać, to wy co myślicie? Ja wam pokażę wojsko. Wiecie, kto } \\
\text { ja jestem? Obergefreiter, skatina jebana w rot... } \\
\text { Nie wiedziałem, czy ostatnie słowa stanowią nader krytyczną samoocenę, } \\
\text { czy odnoszą się do drużyny. } \\
\text { Poszedłem na koniec wsi [...]. (187) }\end{array}$ \\
\hline 27. & $\begin{array}{l}\text { - Nie rozmazuj się, nie jesteś dziewicą - mruknąłem } \\
\text { opryskliwie. (65) }\end{array}$ & $\begin{array}{l}\text { - Nie rozmazuj się, nie jesteś dziewicą w ciąży - mruknąłem opryskliwie. } \\
\text { (193) }\end{array}$ \\
\hline 28. & $\begin{array}{l}\text { - Stójcie, taka wasza mać - wrzasnąłem wściekły na } \\
\text { szperaczy. }(72)\end{array}$ & - Stójcie, jebiona mać - wrzasnąłem wściekły na szperaczy. (198) \\
\hline 29. & - Taka mać, zabiłem przyjaciela. (73) & - Kurwa mać, zabiłem przyjaciela. (199) \\
\hline 30. & $\begin{array}{l}\text { Konie były jak zwykle zmęczone, obojętne, mokrymi } \\
\text { chrapami szukały worka z owsem. } \\
\text { Jakiś świetlny pocisk wystrzelił daleko za lasem i zgasł } \\
\text { w kołach Wielkiego Wozu. (73) }\end{array}$ & $\begin{array}{l}\text { Konie były jak zwykle zmęczone, obojętne, mokrymi chrapami szukały wor- } \\
\text { ka z owsem. Dla mnie wszystko się skończyło, nie widziałem nowego. Nie } \\
\text { znałem wówczas owej złotej mądrości, że wszystko mija, że człowiek wytrzy- } \\
\text { muje wszystko z wyjątkiem własnej śmierci. Jakiś świetlny pocisk wystrzelił } \\
\text { daleko za lasem i zgasł w kołach Wielkiego Wozu. (199-200) }\end{array}$ \\
\hline 31. & $\begin{array}{l}\text { Przyszedłem tu dla plutonu, chociaż pod śniegiem leżał mój } \\
\text { przyjaciel. Wróciwszy do sań, wybuchnąłem: [...]. (75) }\end{array}$ & $\begin{array}{l}\text { Przyszedłem tu dla plutonu, chociaż pod śniegiem leżał mój przyjaciel, który } \\
\text { już teraz nie miał mi za złe tego nieszczęsnego strzału. Żółty trójkąt światła } \\
\text { księżycowego łamał się na świeżym grobie. Stefan przy wnoszeniu go do } \\
\text { chaty, zamroczony bólem, klął mnie od skurwysynów. Pytał nie wiadomo } \\
\text { kogo: - Dlaczego ten drań do mnie strzelił? } \\
\text { Wróciwszy do sań, wybuchnąłem: [...]. (200) }\end{array}$ \\
\hline 32. & $\begin{array}{l}\text { Skręciliśmy na trakt. [koniec rozdziału } \\
\text { ósmego - E. D.] (75) }\end{array}$ & Skręciliśmy na trakt. Za nami pod księżycem została chata. (201) \\
\hline 33. & $\begin{array}{l}\text { Przypominał mi się Stefan. Coraz rzadziej mówili o nim } \\
\text { chłopcy. Bonza zaopiekował się mną [...]. (76) }\end{array}$ & $\begin{array}{l}\text { Przypominał mi się Stefan. Zabiło mi serce, gdy po paru dniach na piersi } \\
\text { Sułtana pojawił się jego ryngraf; ale nie miałem nic do powiedzenia. Bonza } \\
\text { zaopiekował się mną [...]. (202) }\end{array}$ \\
\hline 34. & $\begin{array}{l}\text { Wierzyliśmy, że nasze silne, dobrze uzbrojone oddziały } \\
\text { potrafią zdobyć miasto. Stało się inaczej. ( } 81)\end{array}$ & $\begin{array}{l}\text { Wierzyliśmy, że nasze silne, dobrze uzbrojone oddziały potrafią zawsze } \\
\text { utrzymać miasto. Stało się inaczej. (206) }\end{array}$ \\
\hline 35. & $\begin{array}{l}\text { Urządzanie defilad, mszy polowych i różnych innych } \\
\text { uroczystości wojskowych okazało się fałszywym wykładni- } \\
\text { kiem siły. Takie myśli niewyklarowane i chaotyczne [...]. } \\
\text { (81) }\end{array}$ & $\begin{array}{l}\text { Urządzanie defilad, mszy polowych i różnych innych uroczystości wojsko- } \\
\text { wych okazało się fałszywym wykładnikiem siły. Po akcji na Wilno, w chwili } \\
\text { próby, powtórzył się wrzesień } 1939 \text { roku. Wojna u nas była ciągiem spon- } \\
\text { tanicznych, egzaltowanych zrywów i bolesnych rozczarowań. Takie myśli, } \\
\text { niewyklarowane i chaotyczne [...]. (206) }\end{array}$ \\
\hline 36. & $\begin{array}{l}\text { Odsuwałem je od siebie ze wstrętem. Nie czas było } \\
\text { roztrząsać sprawy należące do tych, którzy w konspiracyj- } \\
\text { nych mieszkaniach w zaułkach wileńskich kierowali naszą } \\
\text { akcją. (81) }\end{array}$ & $\begin{array}{l}\text { Odsuwałem je od siebie ze wstrętem. Walczyliśmy bezkompromisowo. Nie } \\
\text { czas było roztrząsać sprawy należące do tych, którzy w konspiracyjnych } \\
\text { mieszkaniach w zaułkach wileńskich kierowali naszą akcją. (206) }\end{array}$ \\
\hline
\end{tabular}




\begin{tabular}{|c|c|c|}
\hline & Rojsty 1956 & Rojsty 2010 \\
\hline 37. & $\begin{array}{l}\text { Więcej sprytu i żadnych sentymentów. - Tak, tak - pota- } \\
\text { kiwałem. (83) }\end{array}$ & $\begin{array}{l}\text { Więcej sprytu i żadnych sentymentów. Każdy bolszewik to nasz wróg. - Tak, } \\
\text { tak - potakiwałem. (208) }\end{array}$ \\
\hline 38. & $\begin{array}{l}\text { Nasze sprawy, zdające się ostatecznymi i najprostszymi, } \\
\text { wydały mi się teraz jakoś egzotyczne między murami } \\
\text { miasta. (85) }\end{array}$ & $\begin{array}{l}\text { Nasze sprawy, zdające się ostatecznymi i najprostszymi, były tylko fragmen- } \\
\text { tem życia Wileńszczyzny. (210) }\end{array}$ \\
\hline 39. & $\begin{array}{l}\text { Po kąpieli wysmarowałem się obficie szarą maścią, sku- } \\
\text { teczną rzekomo i na świerzb. (87) }\end{array}$ & $\begin{array}{l}\text { Po kąpieli wysmarowałem się obficie szarą maścią, skuteczną rzekomo nie } \\
\text { tylko na mendy, ale i na świerzb. (212) }\end{array}$ \\
\hline 40. & $\begin{array}{l}\text { [...] ale my zostaniemy i wytrwamy do chwili, kiedy } \\
\text { można będzie wkroczyć do wolnego Wilna [...]. (94) }\end{array}$ & $\begin{array}{l}\text { [...] ale my zostaniemy i wytrwamy do chwili, gdy wkroczymy do wolnego } \\
\text { Wilna [...]. (216) }\end{array}$ \\
\hline 41. & $\begin{array}{l}{[\ldots] \text { naklejaliśmy je na słupach telefonicznych. }} \\
\text { Stefana nie było. (96) }\end{array}$ & $\begin{array}{l}\text { [...] naklejaliśmy je na słupach telefonicznych. Pomagaliśmy w tym ludziom } \\
\text { prześladowanym. Ojciec Stefana powtarzał często, że rząd nasz był proży- } \\
\text { dowski. } \\
\text { Stefana nie było. (218) }\end{array}$ \\
\hline 42. & $\begin{array}{l}\text { Zginął, chociaż omyłkowo za sprawę. } \\
\text { Nad Wilią było cicho. (96) }\end{array}$ & $\begin{array}{l}\text { Zginął, chociaż omyłkowo za sprawę. Ale czy miał często wracać w moje } \\
\text { życie? } \\
\text { Nad Wilią było cicho. (218) }\end{array}$ \\
\hline 43. & $\begin{array}{l}\text { Przed wymarszem cyrograf siwego majora ukryłem w pa- } \\
\text { pierowej wkładce do buta. (97) }\end{array}$ & $\begin{array}{l}\text { Przed wymarszem dokument siwego majora ukryłem w papierowej wkładce } \\
\text { do buta. (219) }\end{array}$ \\
\hline 44. & $\begin{array}{l}\text { [...] a dziewczyna, jego żona, funkcjonariuszką komso- } \\
\text { mołu w Mińsku. (102) }\end{array}$ & [...] a dziewczyna, jego żona, przewodniczącą komsomołu w Mińsku. (224) \\
\hline 45. & $\begin{array}{l}\text { - Jaka pani chuda - szepnąłem, żeby jej zrobić przykrość. } \\
(110)\end{array}$ & - Ma pani brzydki biust - szepnąłem, żeby jej zrobić przykrość. (231) \\
\hline 46. & $\begin{array}{l}\text { - Nigdy za dużo ofiar - sprzeciwił się Orzeszek. Pani } \\
\text { Korsakowa siąkała nosem. (112) }\end{array}$ & $\begin{array}{l}\text { - Nigdy za dużo ofiar - sprzeciwił się Orzeszek. - Czy chce Pani, żeby } \\
\text { to plugastwo bezcześciło nam kościoły? Pani Korsakowa siąkała nosem. } \\
(232-233)\end{array}$ \\
\hline 47. & $\begin{array}{l}\text { Z Pogoniami na czapkach. Musztra u nich jakaś niemiecka. } \\
\text { Całe szczęście, że wieczorem niepostrzeżenie odjechaliśmy. } \\
\text { (117) }\end{array}$ & $\begin{array}{l}\text { Z Pogoniami na czapkach. Całe szczęście, że wieczorem niepostrzeżenie } \\
\text { odjechaliśmy. (237) }\end{array}$ \\
\hline 48. & $\begin{array}{l}\text { Wierzyliśmy jednak, że do Berlina Rosjanie nie dojdą, już } \\
\text { wcześniej staną, znużeni długim marszem i wykrwawieni } \\
\text { w walkach z Niemcami. (126) }\end{array}$ & $\begin{array}{l}\text { Wierzyliśmy jednak, że do Berlina Rosjanie nie dojdą, już wcześniej staną, } \\
\text { znużeni i tak długim marszem na amerykańskim sprzęcie. ( } 245)\end{array}$ \\
\hline 49. & $\begin{array}{l}\text { Nie miałem bagażu, przy pasie wisiało tylko parabellum } \\
\text { Bonzy. Broni mieliśmy w bród. Ludzie tylko wykruszali } \\
\text { się jak topniejący na polach śnieg. (127) }\end{array}$ & $\begin{array}{l}\text { Nie miałem bagażu, przy pasie wisiało tylko parabellum Bonzy. Fatalną } \\
\text { pepeszę zostawiłem po cichu gospodarzowi na piecu, gdyż broni mieliśmy } \\
\text { w bród. Ludzie tylko wykruszali się jak topniejący na polach śnieg. (245- } \\
-246)\end{array}$ \\
\hline 50 . & $\begin{array}{l}\text { [...] poskładali torby i karabiny. Słychać było łoskot } \\
\text { spadających z sufitu kropel. (134) }\end{array}$ & $\begin{array}{l}\text { [...] poskładali torby i karabiny. Tak się powtarzał trzeci wrzesień. Słychać } \\
\text { już było łoskot spadających z sufitu kropel. (251) }\end{array}$ \\
\hline 51. & $\begin{array}{l}\text { [...] bielmo na oku skryło się w gęstej sieci zmarszczek. - } \\
\text { Nu sztoż, synok, charoszaja? (139) }\end{array}$ & $\begin{array}{l}\text { [...] bielmo na oku skryło się w gęstej sieci zmarszczek. Przypominał mi } \\
\text { mego dziadka. - Nu sztoż, synok, charoszaja? (255) }\end{array}$ \\
\hline 52. & Dawaj, dawaj durak, ja posmatriu. (141) & Dawaj, dawaj, durnyj, ja posmatriu. (256) \\
\hline 53. & $\begin{array}{l}\text { Ruszyliśmy ciężko wąską ścieżynką do kładki nad Solczą, } \\
\text { wstydząc się naszej słabości. Podczas krótkiego postoju } \\
\text { koło Wiśniczy Bonza zwalił się ciężko obok mnie. - No } \\
\text { co, zabrakło wam jakoś oddechu, starzy wygrzewają } \\
\text { sobie spokojnie kości pod piecem. Uniosłem brwi prawie } \\
\text { obojętnie. - Litość - rzekłem krótko. Bonza zaśmiał } \\
\text { się chropawo. - To chyba gorzej jak litość. Dzieci tracą } \\
\text { grunt pod nogami, a bez żarliwej wiary trudno udawać } \\
\text { Skrzetuskiego. (142) }\end{array}$ & $\begin{array}{l}\text { Ruszyliśmy ciężko wąską ścieżynką do kładki nad Solczą, wstydząc się naszej } \\
\text { słabości. (258) }\end{array}$ \\
\hline
\end{tabular}




\begin{tabular}{|c|c|c|}
\hline & Rojsty 1956 & Rojsty 2010 \\
\hline 54. & $\begin{array}{l}\text { - Koledzy po fachu - mruknął Bonza. - Tylko z małą } \\
\text { różnicą. Kwiatek zbladł. (144) }\end{array}$ & - Koledzy po fachu - mruknął Bonza. Kwiatek zbladł. (259) \\
\hline 55. & Minutową ciszą czciliśmy pamięć poległych. (146) & $\begin{array}{l}\text { Minutową ciszą, my spadkobiercy ich tradycji czciliśmy pamięć swoich } \\
\text { poprzedników. (260) }\end{array}$ \\
\hline 56. & $\begin{array}{l}\text { - A stara Korsakowa niepotrzebnie nosiła żałobę } \\
\text { po synach-partyzantach. Napisali niedawno do niej } \\
\text { z Białegostoku. Są już w Polsce i handlują dolarami. (149) }\end{array}$ & Napisali niedawno do niej z frontu, są w armii Berlinga. (263) \\
\hline 57. & $\begin{array}{l}\text { [...] pokornie i usłużnie odpowiadali po litewsku. Był } \\
\text { to okres prosperity na Nowastrojce. Zapobiegliwi jej } \\
\text { mieszkańcy żyli wtedy nie najgorzej, gdyż utworzono } \\
\text { niedawno getto i po dziesiątkach tysięcy Żydów zostały } \\
\text { piramidy ciuchów: ubrań, pierzyn, naczyń i obuwia. Jeśli } \\
\text { się ktoś bał kraść niepilnowane mienie, mógł bez wielkich } \\
\text { kłopotów kupować to wszystko za psi grosz w specjalnie } \\
\text { przez Niemców utworzonych sklepach. Sułtan chlubił się } \\
\text { swoim nowastrojskim pochodzeniem [...]. (150) }\end{array}$ & $\begin{array}{l}\text { [...] pokornie i usłużnie odpowiadali po litewsku. Sułtan chlubił się swoim } \\
\text { nowastrojskim pochodzeniem [...]. (264) }\end{array}$ \\
\hline 58. & $\begin{array}{l}\text { [...] która mi tak zawadzała jeszcze za czasów niemieckich } \\
\text { w akcji na Taboryszki. (153) }\end{array}$ & $\begin{array}{l}\text { [...] która mi tak zawadzała jeszcze za czasów niemieckich w akcji na Wilno. } \\
\text { (266) }\end{array}$ \\
\hline 59. & $\begin{array}{l}\text { Podczas okupacji w naszej sferze były tylko dwa gatunki } \\
\text { młodzieży: [...]. (153) }\end{array}$ & Podczas okupacji były tylko dwa gatunki młodzieży: [...]. (266) \\
\hline 60. & - Ale bogaty sukinsyn. (155) & - Ale bogaty skurwysyn. (267) \\
\hline 61. & $\begin{array}{l}{[\ldots] \text { zemsta rozsierdzonego dowódcy obwodu AK, rot- }} \\
\text { mistrza Orzeszka. (156) }\end{array}$ & [...] zemsta rozsierdzonego dowódcy obwodu, rotmistrza Orzeszka. (269) \\
\hline 62. & $\begin{array}{l}\text { Jakiś siwy pułkownik, któryś tam z rzędu piastujący } \\
\text { stanowisko dowódcy AK, wyparł się nas, chociaż jesienią } \\
\text { zgodnym, patriotycznym jazgotem razem z innymi nie- } \\
\text { przejednanymi wygonił nas do lasu. (171) }\end{array}$ & $\begin{array}{l}\text { Jakiś siwy pułkownik, któryś tam z rzędu piastujący stanowisko dowódcy, } \\
\text { wyparł się nas, chociaż jesienią zgodnym, patriotycznym jazgotem razem } \\
\text { z innymi nieprzejednanymi wygonił nas do lasu. (281) }\end{array}$ \\
\hline 63. & $\begin{array}{l}\text { Wyszliśmy na twardy trakt. Na fioletowych polach } \\
\text { posuwały się wolno zgarbione konie, a za nimi pochyleni } \\
\text { nad pługiem oracze. Wychudłe wrony podskakiwały na } \\
\text { kleistych skibach, poszukując pokarmu. Za jasnozielony- } \\
\text { mi tumanami młodych drzew czerwienił się dach jakiegoś } \\
\text { dworu. - Ot widzisz - podrzucił brodą Bonza - chłopi } \\
\text { jednak ziemię wzięli i orzą. - Et - westchnąłem. Pod no- } \\
\text { gami skrzypiał żółty żwir. Przed wsią przeżyliśmy pierwszą } \\
\text { emocję. (171) }\end{array}$ & Wyszliśmy na twardy trakt. Przed wsią przeżyliśmy pierwszą emocję. (281) \\
\hline 64. & Ścieżką przy szerokim trakcie poszliśmy do Wilna. (172) & $\begin{array}{l}\text { Ścieżką przy szerokim trakcie poszliśmy do Wilna. } \\
\text { XVIII } \\
\text { W domu przyjęła mnie matka, zdumiona i szczęśliwa. Ja także byłem wytrą- } \\
\text { cony z równowagi takim zakończeniem naszej walki. [...] } \\
\text { Podjąłem lewą ręką kamuszek z trawy i niezdarnie cisnąłem w dół. Woda } \\
\text { przyjęła go z cichym pluskiem, a po gładkiej, zarumienionej tafli przebiegły } \\
\text { kręgi drobnych fal i zaraz zgasły. }(282 \text { i } 285)^{14}\end{array}$ \\
\hline
\end{tabular}

Zestawienie dostarcza materiału do analizy, którą należałoby prowadzić w wielu kierunkach. Z konieczności ograniczę się do najważniejszych różnic (powyższe zestawienie uwzględnia wszystkie wykryte różnice, poza odmiankami o charakterze czysto językowym) między wersją restytuowaną a opublikowaną. Sprawiły one, że Rojsty wydane w wersji autorskiej w 1948 roku byłyby zupełnie inną powieścią aniżeli ich sobowtór z 1956 roku. 


\section{Ostatnia powieść kresowa}

Kazimierz Wyka w artykule o świeżo wydanych Rojstach, zamieszczonym w 1956 roku na łamach „Życia Literackiego”, zatytułowanym intrygująco, a zarazem prowokacyjnie - Ostatnia powieść Orzeszkowej - z lektury utworu Konwickiego odniósł mieszane wrażenia. Przede wszystkim nie poczytał pisarzowi za szczególne osiągnięcie obrazu partyzantki:

Jako opowiadanie o partyzantce i jej bojowej oraz psychologicznej egzotyce, o gwałtownym obnażaniu się typu moralnego i charakteru człowieka w obliczu kul, wilków i partyzanckiego „chodzenia” - Rojsty nie są jakąś rewelacją. Przez autentyczne wspomnienia za dużo przebiega literackiego szwu i mimowolnej ściągaczki szkolnej ${ }^{15}$.

Pisząc o „ściągaczce”, krytyk miał na uwadze m.in. kalki z Wiernej rzeki ${ }^{16}$. W dziedzinie partyzanckiej wyżej cenił zaś książkę Władysława Machejka Rano przeszedt huragan o „podhalańskiej bandzie"17. W Pograniczu powieści przychylnie odniósł się natomiast do żołniersko-partyzanckich opowiadań Wojciecha Żukrowskiego (Z kraju milczenia), widząc w nich odnowienie tradycji sienkiewiczowskiej ${ }^{18}$.

O ile opinię krytyka odnośnie do ujęcia partyzantki w Rojstach z 1956 roku można przyjąć bez większych zastrzeżeń, to powieść w wersji autografowej wypadałoby potraktować łagodniej.

Autor Pogranicza powieści z 1948 roku odnotowywał nikłą frekwencję utworów powieściowych w literackim pokłosiu wojny i okupacji oraz ich artystyczną miałkość. Pisał wówczas o powieści Jana Dobraczyńskiego $W$ rozwalonym domu: „Popularny i dydaktyczno-moralizujący schemat położony na tragedię powstańczą, dziwnie zgrzyta swoim niedopasowaniem do tematu"19. W zestawieniu z Dobraczyńskim Konwicki ze swoją powieścią musiałby wypaść nie najgorzej z tego względu, że również mierzył się z nie lada tragedią - likwidacją wileńskiego ruchu niepodległościowego i - więcej jeszcze - polskości na ziemiach za linią Curzona.

W odróżnieniu od Rojstów z 1956 roku ich autografowa wersja nie była w żadnym razie jeszcze jednym świadectwem „schyłku polskiej partyzantki”" jak zauważył Wyka w swoim komentarzu z „Życia Literackiego”, ale powieścią o partyzantce ściśle określonej co do miejsca i czasu, prowadzonej też w innych warunkach aniżeli partyzantka „w Polsce”. Jeden bowiem z zabiegów manipulacyjnych przeprowadzanych na materiale całego utworu w drodze do publikacji polegał na konsekwent- nym usuwaniu wzmianek o „akcji na Wilno” (fragmenty: 1, 5, 16, 17, 25, 35, 58 i 64), czyli operacji „Ostra Brama”, której celem miało być opanowanie miasta siłami akowskimi ${ }^{21}$. Faktograficznie rzecz biorąc, operacja nie przyniosła siłom polskim zwycięstwa, a próba współdziałania z Armią Czerwoną zakończyła się aresztowaniami dowódców oraz rozbrajaniem oddziałów partyzanckich. $Z$ tekstu powieści akcja wileńska (przywoływana bez żadnych szczegółów) została wymazana, w paru miejscach wprowadzono zaś fałszujące obraz zamienniki - akcję „na Ławaryszki” (16 i 25) bądź „na Taboryszki” (58).

Ingerencja ta nie jest zabiegiem, który czytelnik mógłby sobie zrekompensować domyślnością. Stanowi przy tym bardzo poważne naruszenie całej konstrukcji tekstu. „Akcja na Wilno” jest bowiem w wersji nieocenzurowanej utworu wydarzeniem granicznym: oddziela czasy „niemieckie” partyzantki od czasów „bolszewickich”, czasy jej rozkwitu od fazy likwidowania. Wzmianki o „akcji na Wilno” nadają powieściowej przedakcji rozmach i wymiar historyczny. Fabuła stanowi jedynie odprysk tamtych wydarzeń. Bez „akcji na Wilno” przedstawiona w powieści partyzantka nie ma swojego punktu kulminacyjnego, spektakularnego wyjścia z lasu; rozpada się na wiele rozsianych bezładnie po okolicy potyczek. Przejście z fazy „niemieckiej” do „bolszewickiej” dokonuje się płynnie, bez wyraźnego progu.

Co istotne, „akcja” została usunięta nie tylko jako wydarzenie o znaczeniu historycznym, ale też jako punkt zwrotny w biografii głównego bohatera i zarazem narratora - Żubra. W tekście autografowym „akcja na Wilno” była momentem jego inicjacji bojowej. Żubr nie znał więc z autopsji partyzantki czasów „niemieckich”. Legenda o niej stanowiła natomiast źródło kompleksów względem starych partyzantów, a potem i narastającego rozgoryczenia, kiedy jego własne doświadczenia leśne coraz bardziej rozchodziły się z uprzednimi wyobrażeniami. „Akcja na Wilno” podkreślała inne jeszcze napięcie w świecie powieści, mianowicie antagonizm wileńsko-warszawski, dochodzący do głosu w rywalizacji między Żubrem a przybyszem z Warszawy - Aktorem. W wersji pierwotnej Rojstów konflikt między bohaterami został uwikłany w napięcie między powstaniem warszawskim i ,akcją na Wilno”. W wersji utworu pozbawionej odniesień do próby zdobycia Wilna „męczeńska krew” warszawska straciła swój wileński kontrapunkt. Skreślenie ostatniego, osiemnastego rozdziału spowodowało z kolei, że ów antagonizm nie znalazł ujścia w gorzkim odnarratorskim komentarzu, w związku z powrotem Aktora do Polski razem z eksnarzeczoną Żubra, Ewą:

Ciekawiło mnie, czy Aktor mógł się znaleźć w nowych warunkach. Ale chyba tak. $Z$ pewnością chował w szufladach 
wstążki orderowe, wspomnienie wojennej chwały, do której doszedł jeszcze mit walki z bolszewikami. Był kryty na obie strony. Mógł teraz na dobrej posadce służyć rządowi lubelskiemu, a w razie czego, gdyby tam ktoś na białym koniu wjechał do Warszawy, można było wydobyć zdobyte krzyże i powołać się na nieugiętą walkę z bolszewizmem. Uderzyć się z dumą w pierś. Ale w czyją? Chyba naszą, tych, którzy walcząc w lasach białoruskich, marzyli o mocarstwie, jeszcze w maju $1945 \mathrm{roku}^{22}$.

Powyższy cytat zwraca uwagę na odmienność sytuacji kombatantów walk z Niemcami i tych, którzy zdążyli uczestniczyć jedynie w partyzantce antybolszewickiej. Ci drudzy, jeśli przeżyli, musieli o swoim szlaku bojowym milczeć. Można się zastanawiać, czy z autografowej wersji Rojstów nie dałoby się wyczytać autorskiego dążenia, żeby mimo wszystko - wbrew układowi politycznemu - wprowadzić do zbiorowej pamięci „akcję na Wilno” i jej następstwa ${ }^{23}$. Deheroizację, groteskowość niektórych postaci i zdarzeń, drwinę czy samoponiżenie można by wówczas interpretować nie tylko jako reakcję na klęskę ${ }^{24}$, ale w owej deprecjonującej przedmiot poetyce zobaczyć sposób na przemycenie do obiegu publicznego tematu skreślonego, odesłanego na całkowite zapomnienie. Byłby to więc sposób analogiczny do romantycznego historyzmu maski.

Doceniając autorski manewr, nie można jednak pomijać jego ciemniej-

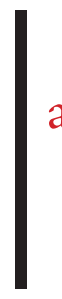
W Rojstach
autografowych repatriacja
stanowi mocny akcent
w rozdziale ostatnim jących, bo przecież tam po białoruskich wsiach i w Wilnie, urodzili się oni, tam żyli ich przodkowie i zaludnili cmentarze. Odbywa się proces, który subiektywnie kosztował wiele łez, wiele żalu, który w sercach i przywiązaniach nie daje się w jednym pokoleniu zagoić. Sprawy, o których nie wolno literaturze milczeć pod groźbą fałszu i lakiernictwa. Ziemie nie były rdzennie polskie, lecz jakże głęboko przepojone naszą kulturą i wspólną historią - miasto celi bazylianów, Wielkiej Improwizacji. Rojsty musiały o tym zamilczećc ${ }^{26}$.

W Rojstach autografowych repatriacja stanowi mocny akcent w rozdziale ostatnim, który rozgrywa się w Wilnie po rozproszeniu oddziału. Wersję z 1956 roku zamykał epizod na drodze do Wilna - pierwszego pokojowego spotkania zdemobilizowanych partyzantów, Żubra i Bonzy, z „bolszewikiem”. W wersji rękopiśmiennej Żubr wraca do domu, z którego już prawie wszyscy wyjechali, a jego matka pakuje rzeczy na podróż. Odbywa się bez łez i innego demonstrowania „subiektywnych” - jak to ujął Wyka - kosztów. Zamiast tego toczy się rozmowa rozrachunkowa między Żubrem a Bonzą, którzy ostatni pewnie raz spotykają się na przechadzce poza miasto. Ważna szej strony, wychodzącej na jaw, kiedy usytuuje się powieść Konwickiego w jej macierzystym kontekście. Kiedy Rojsty powstawały, partyzantka niepodległościowa nie była jeszcze tematem historycznym. Przeciw nowej władzy nadal walczyły niedobitki oddziałów leśnych. Odbywały się procesy złapanych partyzantów, wykonywano wyroki ${ }^{25}$.

Wracając do oryginalności ujęcia partyzantki w wersji autografowej, polega ona jeszcze niewątpliwie na związku tematu partyzanckiego z akcją likwidacyjną polskości na Wileńszczyźnie, czyli z tzw. repatriacją. Właśnie o repatriację upominał się Wyka, komentując Rojsty w 1956 roku, i dlatego też zatytułował swój artykuł Ostatnia powieść Orzeszkowej:

Partyzantowi dla jego politycznego rozrachunku sumienia potrzebny był tylko groteskowy aspekt problemu i intelektualna prowokacja. Więcej nie dał i dać zapewne nie mógł. Jednocześnie po liniach kolejowych przekraczanych nocami przez oddział Kwiatka toczą się pociągi repatriantów wyjeżdżających do Polski. Wyjeżdżających, a nie powraca- jest sceneria dialogu: widok na zbocze wzgórza nad Wilenką, gdzie pochowano poległych w „akcji na Wilno”.

Rozmowa przebiega po myśli obowiązujących wymogów ideologicznych. Jeśli było w niej coś nie do przyjęcia z punktu widzenia cenzury, dałoby się to zapewne bez trudu wyretuszować. O wycięciu całego rozdziału zadecydowało raczej nie to, co bohaterowie do siebie mówią, ale na co patrzą i co zapamiętali:

Na zboczu wzgórza stromo spadającego do Wilenki, między sosnami zieleniały porosłe już trawą groby. Na zmytych przez deszcz krzyżach widać było jeszcze ślady napisów. Miną już prawie rok od czasu, kiedy zwożono tu chłopców, wyszukiwanych w zielonych żytach. Układano ich rzędami, a koledzy identyfikowali poległych. Na krzyżach chwiały się podziurawione hełmy. Pokryły się już dobrze rdzą. W dole gaworzyła Wilenka ${ }^{27}$.

Obok rozprawiających bohaterów przemawiają w tej scenie mogiły - wrośnięte już w krajobraz, po części znaturalizowane, a zarazem wtopione w pejzaż kulturowy Wileńszczyzny jako ziemi od pokoleń ponawianych (pordzewiałe hełmy!) walk niepodległościowych. Mogiły te bowiem tworzą pomost między 1863 rokiem, upamiętniony w powieści krzyżem, przy 
którym partyzanci zatrzymują się w lesie, a ich oporem wobec bolszewików ${ }^{28}$. „Gaworząca” Wilenka kojarzy się nie tylko z „wierną rzeką" Stefana Żeromskiego, ale i z „domową” Adama Mickiewicza $^{29}$. Ostatni fragment powieści mówi o wyjeździe z Wilna, ale też o trwającym przez wiele generacji zakorzenieniu - biologicznym i duchowym.

Wycięcie z powieści ostatniego rozdziału mocno ingeruje również w relacje między bohaterami. Co więcej, radykalnie zmienia wizerunek jednego z nich, mianowicie Bonzy. Dopiero bowiem w usuniętym rozdziale osiemnastym odsłaniały się głębsze motywacje „cynika”30. Bonza, w obu wersjach powieści od początku irytujący bohatera swoimi drwiącymi docinkami i sceptycyzmem wobec sensowności partyzanckiego „chodzenia”, w ostatnim rozdziale okazuje się przedwojennym lewicowcem, asystentem na uniwersytecie, intelektualistą:

Podczas okupacji poprzestałem na sympatiach lewicowych i sceptycyzmie. To wystarczało, żeby uważano mnie za bolszewika. Potem przyszli Rosjanie. Podziemie rozpoczęło wyroki na naszych komunistach [...]. I po prostu stchórzyłem. Kiedy dostał w kołnierz Kubelski, zacząłem się wahać. Miałem swoje intelektualne zastrzeżenia do bolszewików, trochę poddałem się nastrojom naszego kochanego społeczeństwa, a trochę uległem tchórzostwu, ot i tak pewnego dnia znalazłem się w oddziale. A dalej to już zwykle ${ }^{31}$.

W scenie tej rozwiewają się podejrzenia - również przezornie wykreślone z tekstu przed publikacją - jakie bohater żywił wobec Bonzy, domyślając się w nim wtyczki NKWD (zestawienie cytatów nr 19). Finałowa rozmowa ekspartyzantów pokazuje zbliżenie stanowisk Bonzy, zakamuflowanego lewicowca, i Żubra - do niedawna żarliwego zwolennika oporu „do ostatka”, a co do opcji politycznej partyzanta o skłonności endeckiej. W świetle ostatniej sceny zrozumiały też staje się ton narracji, prowadzonej z dystansu, bezlitosnej dla złudzeń i patriotycznych wmówień. Ostania scena pozwala czytelnikowi zrozumieć, że ów ton narrator przejął właśnie od Bonzy jako nowego mentora i że spogląda na partyzantkę z pozycji lewicowych. Usunięcie ostatniego rozdziału likwiduje przejście od cynizmu do lewicowości, tym samym zaś przemiana postawy bohatera i narratora zarazem ogranicza się wyłącznie do deziluzji, spełnia się natomiast w szyderstwie z własnych złudzeń.

W wersji opublikowanej w 1956 roku zarażony cynizmem bohater skłania do niepokoju o jego los. Wychodzi z lasu na drogę do Wilna - tak kończy się powieść - w stanie skrajnego zagubienia, konfrontując się od razu z dobrotliwym bolszewikiem, na widok którego reaguje najpierw przerażeniem, potem konsternacją. Takie zakończenie powieści zostawiało czytelnika z pytaniem, co dalej. Czy ekspartyzant znajdzie swoje miejsce w powojennej rzeczywistości? Zakończona rozdziałem osiemnastym wersja rękopiśmienna nie skłaniała do obaw o bohatera, ale raczej wskazywała jemu podobnym wyjście z leśnego labiryntu ku przyszłości: otóż za błędy partyzanckiej młodości należało obwinić terror patriotyczny. W tej wersji powieść mówiła zatem nie tylko o absurdzie schyłkowej fazy partyzantki niepodległościowej, ale też instruowała, jak z niego wyjść. Wielu akowców drogę taką odbyło, Konwickiego nie wyłączając.

\section{Summary: "Rojsty" 1957/2010. Remarks on the causative stigma of censorship}

Key Words: Tadeusz Konwicki, Rojsty, Książki wybrane, Polish People's Republic, differences between the editions, censorship in Poland

In 2013, an impressive critical edition of In Stablgewittern by Ernst Jünger, bringing seven further authorial versions from the years 1920-1978, was published in Germany. The author of the article correlates that undertaking with the publication of Konwicki's Ksiażki wybrane under the auspices of Agora. Some parts of the text removed by censors became restored but not marked. The thread of editorial considerations is followed by the author's demand to prepare editions of at least ten works from universally acclaimed canon determined in the Polish People's Republic, which would be critically annotated and make both integral versions of the text available under one cover. Considering the interpretation of both versions of Rojsty: published in 1956 and the one issued in 2010, which is identical to the original work published in 1948, the author meticulously juxtaposes the most crucial differences between the editions. She states that censorship removed all references to Operation "Ostra Brama" from the novel. In the author's version these references give the novel a deeper historical breath. After removing Operation "Ostra Brama”, the guerrilla presented in the novel lost its climax: the fateful coming out from the forest, and it fell apart into a number of grotesque episodes. Due to Operation "Ostra Brama" present in the novel it is possible to see in various narrative techniques, which depreciate military effort, the tribute repaid by the writer to the authorities in return for the opportunity to inject into public circulation an issue doomed to oblivion.

W oryginale wydanie to określa się jako "historyczno-krytyczne”.

Ł. Musiał, Porucznik Jünger w okopach wielkiej wojny, „Przegląd Polityczny” 2014, nr 125, s. 154

Dwutomowe „historyczno-krytyczne” wydanie In Stahlgewittern reklamuje się w sieci jako sensację edytorską. W „Przeglądzie Politycznym” zamieszczono taką oto jego charakterystykę: „Tysiąc dwieście stron z okładem, rzeczowe wprowadzenie o rozmiarach monografii absolutnie wszystkie wersje książki skomentowane w najdrobniejszych szczegółach, łącz- 
